\title{
COMPARATION OF WAREHOUSE RECEIPT, PAWN AND FIDUCIARY \\ IN THE SECURITY LAW PERSPECTIVE
}

\author{
Iswi Hariyani \\ Faculty of Law, University of Jember \\ Email: ayahbundacita@gmail.com
}

\begin{abstract}
Warehouse Receipt System (WRS) has been used in Indonesia as an instruments of trade and finance to agribusiness commodities since the enactment of Law Number 9 of 2006 and The Central Bank Regulation Number 9 of 2007. The Regulation Number 9 of 2007, Article 46 letter f, allows the use of Warehouse Receipt as a credit collateral. Implementation of Warehouse Receipt System is expected to help farmers, planters, fishermen who have often had difficulty costs at harvest time. As securities, Warehouse Receipt can also be used as an investment instrument in the commodity market. This research aims to find answers of three main problem. First, to examine legal position of Warehouse Receipt in Security Law perspective. Second, to examine differences and similarities of Warehouse Receipt collateral to the Pawn guarantees. Third, to examine differences and similarities between Warehouse Receipt collateral with Fiduciary guarantees.
\end{abstract}

Keywords: Security Law, Warehouse Receipt, Pawn, Fiduciary

\section{A. INTRODUCTION}

\section{Research Background}

Commodity market and financial market has a great influence to maintain the economic stability. Commodity market are not only about futures trading, but also include commodity auction market and warehouse receipt system. Commodity auction market is widely used by businesses to doing transactions of primary commodities by cash, spot or forward. Otherwise, warehouse receipt system have a role to help the handover of goods, so that the commodity buyer no need to seeing the existence of goods in warehouse directly. They just need to checking the document and confirmed it to the authorized.

The common problem of agribusiness in Indonesia, particularly regard to small farmers, are the price has been falling during the harvest 
season. This kind of situation often happened especially on rice farmers because they tend to have the same planting schedule so that the harvest time come at the same time. The same planting schedule was intentionally choosen by the farmers in order to give allocation of irrigation for rice plants, minimized pest and disease attack, and to achieve the optimal planting season. The consequences is the harvest time tend to coincide so it could affected the fall of grain prices. The rice farmers cannot store their harvest longer because they ran out money and don't have an adequate warehouse. This condition is very profitable for middleman and moneylenders who taking advantage from farmers. The middleman tend to be the accomplice of a large warehouse owner both indonesian state owned entities (BUMN) and private (J.A. Noertjahyo, 2005: 65).

The classic problem of commodity price decline at the harvest period has been handled by government and parliament through commodity auction market, credit for businesses program and warehouse receipt system. The application of warehouse receipt system based on The Warehouse Receipt System Act had tried to give solution about that. Farmers no need to rush for selling their crops because now they can store them in the accredited warehouse specified by the government, they also could use warehouse receipt as collateral on bank loans. In case the market's price improved in the future, farmers could selling their crops to pay off the bank loan and get a profit from the remaining proceeds from the sale of goods.

Implementation of warehouse receipt system may give benefits to the farmers, traders, creditors and warehouse manager. Farmers can use warehouse receipt system as collateral so they can postpone the sale of the crop until the price is in the highest position. The bank may extend credit with warehouse receipt as a collateral that easy to excecuted if the debtors broke the promise. Traders can take advantage of warehouse receipt as an instrument in the commodit market (Philine Wehling and Bill Garthwaite, 2015: 2). 
What happened today is the farmers' crop cannot be used as collateral because there is no rule of law about it. However, the problem started to be solved since the publication of Law Number 9 of 2006 on Warehouse Receipts System as amanded by Law Number 9 of 2011 (The Warehouse Receipt System Law) along with the implementing regulations which are The Goverment Regulations Number 36 of 2007, The Regulation of Ministry of Home Affairs Number 26 of 2007 also some regulations from The Commodity Futures Trading Regulatory Agency. Furthermore, The Central Bank of Indonesia has also issued regulations such as The Regulation Number 9/6/PBI/2007 that governs about warehouse receipt as one of the collateral (article 46 letter f).

Warehouse receipt system is one of the main and effective instrument in trade finance system. Warehouse receipt system can facilitate the provision of loans with warehouse's inventory as collateral. It also useful in stabilizing market prices by facilitating the sales way throughout the year. Moreover, warehouse receipt system can be used by the government to manage price and national supply .

Nowadays, the crops that could be stored in warehouse for warehouse receipt system, based on The Regulation of Ministry of Home Affairs Number 26 of 2007 Article 4 Paragraph 1, only include eight types : grain, rice, corn, coffee, cacao, pepper, rubber plant and seaweed. Warehouse receipt issued by a warehouse manager based on commodities stored after getting certified from The Institute of Conformity Assessment. The certification process of warehouse receipt system is the written guarantee by The Institute of Conformity Assessment which states that goods, services, process, system or personnel has met the required standard. There are three basic issuances of warehouse receipts : (a) based on contract, (b) based on membership, and (c) based on The Warehouse Receipt System Act. Warehouse receipt issued based contract cannot transferable and is not a document of title. Warehouse receipt issued bassed on membership only applies to members. Warehouse receipt issued 
by The Warehouse Receipt System Law may be traded and used as collateral to obtain funding (Jamin Ginting, 2008: 17).

Warehouse receipt as a document of title may be used as collateral because it is guaranteed by the certain commodity under the supervision of warehouse manager. Warehouse receipt system is an integral part of the marketing system which has been develod in various countries. The system has proven capable in improving the efficiency of the argo industry sector, both the producers and the commercial sector can change the status of the stocks of raw materials and semi-finished materials into a product that can be sold widely. It was possible because the Warehouse Receipt is also a financial instrument that can be traded, exchanged, and in futures trading can be accepted as a means of settlement of futures transactions.

Business funding through the warehouse receipt system can be obtained from banking institutions, non - bank financial institutions, as well as from investors who interested to buying derivations through futures exchanges or outside of it. In this way, warehouse receipt can rotate many times so it can increase the volume of trade and financial transactions which expected to stimulate national economic progress.

The implementation of warehouse receipt system is now further enhanced by the government by building a warehouse that has been accredited as much as possible in the center of agricultural production, plantation and fisheries in Indonesia. The government also initiated a policy of subsidizing the warehouse receipt based on The Regulation of The Minister of Finance Number 171 / PMK.05 / 2009 on Subsidy Scheme of Warehouse Receipts and The Regulation of The Minister of Trade Regulation Number 66 / M - DAG / PER / 12 / 2009 on The Implementation of Warehouse Receipt's Subsidy Scheme. This facility is provided to farmers, farmers, farmers' group and union who have a productive business. 
The flexibility of warehouse receipt as an instrument of trade and finance regulated in The Warehouse Receipt System Law, Article 4 Paragraph (1) and (2) which states that warehouse receipt may be transferred, used as collateral, or used as shipment document. Warehouse receipt as a document of title may be used as a debt guarantee completely without required any other collateral. According to article 11 of The Warehouse Receipt System Law, transfer of warehouse receipt can occur for the following reasons : inheritance, grant, trade and other reasons permitted by law, include ownership due to the dissolution of business entities which was originally a warehouse receipt holder.

Warehouse receipt document can be transferred many times, so according to The Warehouse Receipt System Law in Article 17 Paragraph 2 , warehouse manager is only required to hand over the goods to the latest warehouse receipt holder. This kind of mechanism could make the trading system more efficient and effective due to the following reasons :

a) Transactions is much easier because it is quite simply carrying warehouse receipt documents

b) Goods stored in warehouse does not need to be taken or moveable

c) It can eliminate the cost of moving goods from warehouse

d) It can prevent damage and loss of goods

e) Warehouse Receipt is also more easily executed by the bank if a breach of contract occured

Warehouse receipt currently has been secured by the Institution of Warehouse Receipt Guarantee. Institution of Warehouse Receipt Guarantee is an Indonesian legal entity that have a task to guaranteeing the rights and interests of warehouse receipt holder or a beneficiary rights against failure, negligence, or warehouse manager's inability to store and deliver the goods. This institutions was established as a mandate from The Warehouse Receipt System Law. The Institutions who responsible to the Ministry of Trade is located in Jakarta and could have representative offices in all regions of Indonesia. Each warehouse managers who 
conducting business in Indonesia shall be a participant of the Institution of Warehouse Receipt Guarantee.

There are many people who do not understand about the Warehouse Receipt until now, which is linked to pawn and fiduciary system. This prompted the author to conduct a study about warehouse receipt in the perspective of security law and examines the differences and similarities on warehouse receipt, pawn and fiduciary. Through this study, it is expected that the bankers, bank customers, entrepreneurs, investors in commodity markets and functionary can understand and practice the implementation of warehouse receipt in a better way.

\section{B. PROBLEM STATEMENT}

The research problem consists of three main points :

1. What is the position of warehouse receipt in the perspective of security law?

2. What are the differences and similarities between warehouse receipt and pawn?

3. What are the differences and similarities between warehouse receipt and fiduciary?

\section{RESEARCH METHODS}

This study aims to assess the comparison of the warehouse receipt, pawn and fiduciary from the perspective of security law. The method used includes statue approach and conceptual approach. Statue approach is done by examining all laws and regulations relevant to the legal issues. The conceptual approach was analyzed from viewpoints and doctrines that developed within the law (Peter Mahmud Marzuki, 2016: 133).

\section{RESEARCH RESULT AND DISCUSSION}

\section{Warehouse Receipt in the Perspective of Security Law}


Guarantees in the juridical perspective interpreted as an attempt to give legal certainty to creditors (the entitled party) that the debtor (the obligated party) shall perform its obligations. In practice, guarantees often narrowly defined by their contractual relationship that is specifically made by the parties to ensure the debtor will implement its obligations. In case, if it is not implemented, so the guarantees role to ensured that creditors obtains what they are entitled. Guarantees in a narrow sense can be interpreted either individual guarantees (borgtocht) and collateral material (Lastuti Abubakar, 2015: 8).

Security law can be simply interpreted as a law that rule about guarantee, either in the form of fixed collateral and personal guarantee (borgtocht). According to Subekti, guarantee can classified to fixed collateral and personal guarantee. Personal guarantee is an arrangement between creditor and third parties who ensures the fulfillment of the debtor's obligations. The agreement of personal guarantee can even be held without noticed from debtor. Fixed collateral can be held between creditor and debtor, or between creditor and third parties that ensures the fullfilment of the debtor's obligations (R. Subekti, 1982: 25).

Fixed collateral include movable assets and immovable assets. The guarantee of immovable asets known as encumbrance rights, whereas movable assets known as pawn and fiduciary. The main function of guarantee is to convinced bank / creditor that debtor have an ability to pay off loans according to the terms and the credit agreement that have been agreed together (Abdul R. Saliman, Hermansyah, 2005: 16). According to The Warehouse Receipt System Law and The Central Bank Regulation Number 9 of 207, Article 46 letter f, warehouse receipt had classified into collateral of movable assets. Warehouse receipt is a further development of fiduciary, while fiduciary is a further development of pawn.

Fixed collateral when viewed from the authority of debitor on holding the collateral can divided to two different group : (a) creditor hold the collateral, and (b) creditor does not hold the collateral. Examples of the 
first type are pawn and retention rights, while an example for the second type are fiduciary, encumbrance rights, buy \& sell, and mortgage (Thomas Soebroto, 1995: 34).

Warehouse receipt based on the explanation above could classified as a guarantee where the creditor is not holding the collateral. It's not held by the creditor and the debtor, but at third parties which is an accredited warehouse manager. The regulation of security law that related to personal guarantee of borgtocht regulated in Burgerlijk Wetboek (BW), third books about engagement, chapter XVII about debt underwriter, Article 1820 to 1850. Definition of personal guarantee or borgtocht according to Article $1820 \mathrm{BW}$ is an engagement where the third parties for creditor's interests, bind themselves to fullfil the debtor's engagement, in case debtor cannot fullfil it. In other words, personal guarantee is a promise between creditor and third parties that willing to ensure the fullfilment of debtor's obligation if debtor's broke his promise.

Personal guarantee contains the legal consequences if debtor proven breach. Creditors entitled to ask for the repayment of debt to debtor and if not enough then the creditor is entitled to ask fo the rest of the repayment to the person who acts as a guarantor of the debt. The privilege owned by creditor can be obtained from the provision of guarantees to certain creditors. These privileges allow creditors to sell the collateral ahead of other creditors. Fixed collateral is set to follow the characteristic of the colateral objects. Guarantee of immovable assets (land and building) had regulated in Law Number 4 of 1996 On Encumbrance Right Over Land and Land Related Objects.

Fixed collateral over immovable assets consist of : pawn, fiduciary, and warehouse receipt. Warehouse receipt regulated in The Civil Code (Burgerlijk wetboek or called BW), book 2, chapter XX, article 1150 1160. Fiduciary is regulated in Law Number 42 of 1999 regarding Fiduciary. Warehouse receipt regulated in Law Number 9 of 2011 or known as The Warehouse Receipt System Law. Furthermore, pawn and 
mortgage of ships and aircraft with a size of 20 cubic metres or more still governed under Book 2 of BW and Law Number 15 of 1992 on Aviation.

Guarantee rights are a legal rights owned by creditors who hold fixed collateral. These creditors also called separatists creditor. Separatists creditor have privilege rights because :

a) They have full authority to executed the guarantee rights if the debtor defaults

b) They have rights to sell a collateral object ahead of other creditors through a public auction or direct sale and gain sales to pay off the debt

Privilege is a right granted by law to specific creditors based on the characteristics of their bills for compensation precedence over a debtor's goods either whole result or partially from it. Separatists creditor's rights on pawn and mortgage had regulated by BW, article $1132-1135$. Separatists creditor's rights on Encumbrance had regulated by Law Number 4 of 1996 regarding Encumbrance, article 21. Separatists creditor's rights on fiduciary had regulated by Law Number 42 of 1999 On Fiduciary, article 27 paragraph (3). Separatists creditor's rights also regulated by Law Number 37 of 2004 On Bankruptcy and Suspension of Debt Payment Obligation, article 55 paragraph (1).

Separatists creditor's rights on warehouse receipt had regulated by The Warehouse Receipt System Act, article 16 paragraph (1) - (3). Article 16 paragraph (1) states if collateral right's giver has broke their promise, they have a rights to sell collateral objects under their own authority through public auction or direct selling. Explanation of article 16 paragraph (1) declares that the provision is intended that the recipient of collateral right have their execution rights through public auction or direct selling with no need a court decision. Execution mechanism on collateral object without fiat / decision from court common nammed with Parate Executie.

Law Number 9 of 2006, article 16 paragraph (2) states that collateral rights recipient have a rights to take the repayment of their debt 
from the sales results as referred to paragraph (1) after deducting the cost of sales and management. Explanation of Article 16 Paragraph (2) declares that the definition of management costs include the cost of storage and insurance costs. Furthermore, Article 16 Paragraph (3) declares that sales of security object can only be done on approval of the guarantee right giver. Explanation of Article 16 Paragraph (3) declares that prior to the execution of security object, guarantee right receiver must give a written notice to guarantee right giver. Based on this, it can be concluded that the creditors are not required to seek approval from debtors if creditors want to execute or sell security objects when the debtors defaults.

\section{The Differences and Similarities of Warehouse Receipts and Pawn}

Provisions about pawn had been regulated by BW, Book 2, Chapter XX, Article 1150 - 1160. Definition of pawn according to Article $1150 \mathrm{BW}$ is rights acquired by the creditors over the immovables assets, entrusted to her by the creditor or by proxy as a collateral for debts, and give authorizes for creditors to take repayment from assets ahead of other creditors; with an exception of sales costs as an implementation of decisions on claims concerning the ownership and control, and the cost of goods rescue, which was issued after the goods were pawned and this should take precedence.

The implementation of pawn is done by pawnshop. Pawnshop is a non - bank financial institution that provide credit to the public that have been known in Indonesia since 1901. Pawn regulated in Article 1150 1160 of The Civil Code and institutionally regulated in Goverment Regulations Number 10 of 1990 On Pawnshop. Pawnshop now dominated by The Pawnshops. FSA (Financial Services Authority) today opened the company's establishment opportunities of private pawnshops.

The occurence of pawn pass through 2 (two) stages :

a). First stage : The first stage is the agreement to borrow money with the promise to provide movable assets as collateral, where this agreement are konsensuil and obligatoir, 
b). Second stage : The second stage is deliver pawn goods to pawn receiver (creditor). Pawn objects is a moving goods so that must be released from debtor (Thomas Soebroto, 1995: 33).

Seen from the definition of Article 1150 of The Civil Code is clear that pawn goods is a moving goods. It is also required by The Circular Letter of The Central Bank of Indonesia Number 4/248/UUPK/PK of March 16, 1972. In adition to the moving goods, the object can be accepted as pawn objects is a moving assets that intangible as regulated in Article 1152, 1152 bis and 1153 of The Civil Code : credit, sight draft / sight bill and order letter (H.R. Daeng Naja, 2005: 269).

According to H.R. Daeng Naja, terms of pawn including :

a). There must be a debt arrangement as a principal arrangement

b). There must be a pawn arrangement as a following arrangement or accessoir arrangement

c). There must be a goods handover to be pledged as collateral

d). Pawn goods only switching control and places, not ownership, from debtor to creditor

e). Pawn goods can be under the control of a third party with the consent of debtors and creditors.

f). Pawn goods should not be under the authority of the debtor (H.R. Daeng Naja, 2005: 271).

According to Oey Hoey Tiong, there are 4 (four) esential elements in pawn :

a). Pawn exist from the handover of authority over pawn goods from debtor (pawn giver) to creditor (pawn taker)

b). The handover of authority can be done by the debtor (pawn giver) or by another person on behalf of the debtor

c). The goods which became the pawn goods merely a moving goods

d). Creditor (pawn taker) is entitled to take repayment of the pawn goods ahead of other creditors (Oey Hoey Tiong, 1984). 
Regarding to analysis above, seem obvious differences between warehouse receipt and pawn, which is pawn have an elements of the full handover of authority over the goods as collateral from debtor to creditor. Pawn goods are entirely at the mercy of creditors, so creditors cannot lease, utilize, or resell goods freely. Otherwise, on the warehouse receipts system, the collateral deposited by a third party (warehouse manager) so the debtor can still transfer or trade goods. Regarding to the facts so it can conclude that warehouse receipt system more accentuates trust between debtor and creditor.

Similarities between pawn and warehouse receipt are the objects is moving goods, and they are both give a special right or first chance to creditor to take a repayment upon sales collateral if the debtor is proven default.

Although the object on pawn and warehouse receipt equally as chattels but there is a differences :

a). Moving goods that can be used as pawn collateral has a wider types

b). Moving goods that can be used as collateral more limited, i.e. agricultural / plantation / certain fisheries, based on The Regulation of the Minister of Home Affairs Number 26 of 2007 including grain, rice, corn, coffee, pepper, rubber plant and seaweed.

Others similarities between pawn and warehouse receipt are their arrangement both an accessoir from a loan agreement as main arrangement. The difference, warehouse receipt must be made in the form of an authentic dead while the pledge agreement is not.

\section{The Differences and Similarities of Warehouse Receipts and} Fiduciary

Fiduciary comes from word fides means "trust". Legal relationship between debtor (fiduciary giver) and creditor (fiduciary receiver) based on trust. Fiduciary giver believe that creditor willing to restore te property rights that have been assigned to him after the debtor repay their debts. 
Creditor also believes debtor will not abusing the collateral that is in his authority and will preserves this goods.

According to Subekti, Fiduciary means "removal of ownership in trust" or fiduciaire eigendomsoverdracht (F.E.O). The word "fiduciary" means "in trust" refer to trust given on a reciprocal basis by one party to another, that what is "out revealed as the transfer of property of", actually just a "guarantee" for a loan. Fiduciary initially refer to the guarantee in the form of moving goods, but as time goes by has also been used against fixed objects. For the immovable goods that can not be subjected Mortgages, Soedewi Maschun Sofwan in her dissertation suggested the use of fiduciary institution (R. Subekti, 1982: 75).

In general, items that can be the object of Fiduciary is movables, either already exist or will exist. Moving goods which can be used as a Fiduciary such as : household utensils (furniture, radio, refrigerator, sewing machine), vehicles (motor bike, car, trcuk), farming tools, company inventories, piles of tobacco in warehouse, shop supplies, retailer's inventories (Sri Soedewi Masjchun Sofwan, 1977: 31). Future goods that can be the object of Fiduciary is the goods that at the time of the fiduciary still not yet exist but will be obtained later. Fiduciary of future goods often used as collateral for a loan in the running account, or used to funding the supply of goods and bills. By the time they arrange a fiduciary deed, debtors who have not become the owner of the objects shall state that curent goods and future goods will added as collateral.

Fiduciary had been regulated by Law Number of 1999 On Fiduciary. Fiduciary is a development of pawn, therefore the object of the guarantee is a moving goods, either tangible or intangible, also immovable goods especially building that cannot be a subject of encumbrance. Fiduciary is a transfer of object ownership on trust with provision that the goods is still on owner's authority. Fiduciary is also an accessoir from a main arrangement which creates obligations for the parties to meet an achievement. In its application, assesment of goods with fiduciary must be 
formalized by a notary and is known as a fiduciary deed Muhamad Djumhana, 2000: 146).

Goods are delivered as collateral in Fiduciary are goods that are economically able to support business flow, such as : vehicles, merchandise inventory, etc. It does not lead to delays in business activities because collateral delivery in fiduciary done by constitum possesorium, which means items to be transferred as collateral remain in debtor's control, but because of the proprietary rights has been submitted to the creditors so the use of collateral by the debtor only have the status of lease (H.R.Daeng Naja, 2005: 278).

According to H.R. Daeng Naja, the fiduciary requires that :

a). There must be a loan agreement as a main agreement

b). There must be a fiduciary agreement as an accessoir

c). There must be a concensual agreement which means the debtor borrowed some money and promised to handed over his property as a fiduciary to creditor as collateral with fiduciary basis to creditors

d). There must be a material agreement by constitutum possessorium, which means the goods still in debtor's authority

e). There must be a lease agreement

Before the enactment of Law Number 42 of 1999 On Fiduciary, goods which become the object of Fiduciary is a moving objects which consists of inventory, receivables, machinery equipment, and vehicles. Since the implementation of Law Number 42 of 1999, definition of fiduciary objects becomes more widespread includes items of tangible and intangible, and property that can not be burdened with Encumbrance (H.R.Daeng Naja, 2005: 282).

According to Munir Fuady, fiduciary administration through a process known as constitutum possessorium which consists of 3 (three) phases :

a) Obligatoir agreement phase. 
An obligatoir agreement can be the agreement to borrow money with fiduciary basis between fiduciary giver (debtor) and creditor (fiduciary receiver)

b). Material agreement phase.

Material agreement can be in the form of delivery of property from the debtor to the creditor by constitutum possessorium or the delivery of property rights without giving up the physical object.

c) Lease agreement phase.

In this phase they have made leasing agreement, where fiduciary object can be leased to the debtors after moving his property to creditors. This means that after being tied up with fiduciary so that the object of fiduciary physically remains controlled by the debtor (Abdul R. Saliman, 2005: 37).

Provisions concerning objects that can be the object of Fiduciary contained in Article 1 Paragraph (4), Article 9, 10 and 20 Law Number 42 of 1999 regarding Fiduciary. Objects that can be the object of fiduciary must be :

a). The object must be owned and transferred legally

b). Tangible object

c). Intangible object, include receivables

d). Movable object

e). Immovable objects that can't be tied to encumbrance

f). Immovable objects that can't be tied to mortgage

g). Objects that already exist, nor future objects.

h). Unit of object or one type of object

i). More than units of objects, or more than one type of object

j). Results from the objects of fiduciary

k). Insurance claims from objects that become the object of Fiduciary

1). Trade inventory (Munir Fuady, 2000).

According to Munir Fuady, fiduciary contains several principles : 
a). In real terms, fiduciary holder only serves as the holder of a guarantee, not as the actual owner

b). Fiduciary holder's right to executing the collateral emerging after debtor defaults

c). After the debt is paid off then the fiduciary object must be returned to fiduciary giver

d). In case, proceeds of fiduciary goods exceeds the amount owed, the remaining proceeds must be returned to fiduciary giver

Based on description above, it can be concluded that the warehouse receipt is one part of fiduciary, namely fiduciary which involving inventory or stock, particularly goods from crops, plantation dan fisheries. As well as fiduciary, warehouse receipts also prioritized the aspect of trust between debtors and creditors. Warehouse receipt agreement and fiduciary are also an accessoir agreement from a loan agreement as principal agreement. The agreement of warehouse receipt and fiduciary also must be made in the form of an authentic deed (notarial deed).

According to Mariam Darus Badrulzaman, fiduciary owner has the right to do parate execution which is the right to collect receivables from the sale of collateral object without executorial title. The owner of fiduciary also has preferential rights, so if the fiduciary giver bankrupt, then the fiduciary objects do not fall into bankruptcy and fiduciary owner's status as a secure creditor is entitled to sell fiduciary objects for the repayment of its receivables (Mariam Darus Badrulzaman, 1987: 98). The differences between warehouse receipt and fiduciary are :

a). In the warehouse receipt system, trade inventories belonging to the debtor must be stored in an accredited warehouse and managed by third party

b). In the rarehouse receipt system, there is a substitute document called the warehouse receipt that can be used as a "proof of ownership of goods". The warehouse receipt can be transferred, sold, and used as 
collateral. In fiduciary there is no substitute documents such as warehouse receipt that can be transferred, sold and used as collateral.

c). The type of goods which can be used as fiduciary objects has more kinds than the objects of warehouse receipts. The goods that can be used as the object of warehouse receipt are currently limited to eight commodities in agriculture, plantation and fisheries : grain, rice, corn, coffee, cocoa, pepper, rubber, and seaweed.

\section{E. CLOSING}

Warehouse receipt, in the perspective of security law, classified as collateral for moving objects as well as pawn and fiduciary. The difference is, the object of collateral in warehouse receipt system hold by the accredited warehouse manager, while pawn's collateral hold by creditors, whereas the object of fiduciary hold by debtors with lease status. The owner of warehouse receipt's object was given a warehouse receipt documents that can be transferred and traded. There are no such document as it in pawn and fiduciary.

The similarities of warehouse receipt, pawn and fiduciary, include :

a). The collateral object is equally classified as moving goods.

b).Pawn, fiduciary and warehouse receipt are an accessoir agreement from a loan agreement as a principal arrangement.

c). Recipients of pawn, fiduciary and warehouse receipt equally privileged to to sell collateral objects on its own without fiat / court decision when debtor defaults. This kind of mechanism commonly called Parate Executie.

d). Rightsholders of pawn, fiduciary and warehouse receipt in case of bankruptcy that affecting debtors, have the same status as a separatists thus equally entitled to precedence in the sale of collateral object

The differences of warehouse receipt, pawn and fiduciary, include :

a). Pawn is a guarantee of movable assets, which the controlling of collateral object remains in the hands of creditors. 
Fiduciary is a guarantee of movable assets and immovable assets which can not be tied up with mortgage, which the controlling of collateral object remains in the hands of debtor (fiduciary recipient) with Right to Use.

Warehouse receipt is a guarantee of movable assets especially commodity from agriculture / plantation / fisheries, which the controlling of collateral object remains in the hands of warehouse manager but debtors can still trade in or transfer its warehouse receipt documents.

b). The agreement of fiduciary and warehouse rceipt must be arranged in the form of a notarial deed, while pawn do not have to arranged in the form of a notarial deed

c). Kinds of movable assets that can be used as the object of Pawn and Fiduciary has miscellaneous types, while movable assets which can be used as objects of warehouse receipts is limited i.e. only agricultural / plantation / fisheries such as grain, rice, corn, coffee, cacao, pepper, rubber plant, seaweed.

d). Warehouse receipt documents is more flexible because it can be transferred, transferred, traded many times, and can be used as collateral / guarantee credit.

e). Warehouse receipt document can be made into a variety of derivative products (such as futures, options, index, discounted securities and units of warehouse receipt) which can be traded on the stock market and outside the futures exchange.

f). Warehouse receipt classified as safe securities because it's been secured by the Institutions of Warehouse Receipt which is under the control of the Minister of Trade. On the other hand, the document of pawn and fiduciary not classified as securities that can be traded on commodity exchanges.

The bankers, entrepreneurs, investors, farmers, officials and other parties related to the implementation of warehouse receipt system expected to understand correctly the similarities and differences of warehouse receipt, pawn and fiduciary from the perspective of security law. This is necessary so 
that they can practice the warehouse receipt system according to the rules of law and principles of good business.

Table : Comparation of Warehouse Receipt, Pawn and Fiduciary

\begin{tabular}{|c|c|c|c|}
\hline Points & Warehouse Receipt & Pawn & Fiduciary \\
\hline Legal Basis & $\begin{array}{c}\text { Law Number } 9 \text { of } \\
2006 \text { jo Law Number } \\
9 \text { of } 2011 \text { (The } \\
\text { Warehouse Receipt } \\
\text { System Act) } \\
\text { and } \\
\text { The Central Bank of } \\
\text { Indonesia Regulation } \\
\text { Number } 9 \text { of } 2007\end{array}$ & $\begin{array}{c}\text { The Civil Code } \\
\text { Article } 1150- \\
1160\end{array}$ & $\begin{array}{c}\text { The Law } \\
\text { Number } 42 \text { of } \\
1999 \text { on } \\
\text { Fiduciary } \\
\text { (The Fiduciary } \\
\text { Law) }\end{array}$ \\
\hline $\begin{array}{l}\text { Collateral } \\
\text { Agreement }\end{array}$ & Mandatory & Mandatory & Mandatory \\
\hline Notary Deed & Mandatory & Not Mandatory & Mandatory \\
\hline Security Object & $\begin{array}{c}\text { Movable goods in } \\
\text { agriculture, plantation } \\
\text { and fisheries }\end{array}$ & $\begin{array}{c}\text { Movable goods in } \\
\text { general }\end{array}$ & $\begin{array}{c}\text { Movable goods } \\
\text { in general and } \\
\text { unit of flats }\end{array}$ \\
\hline
\end{tabular}




\begin{tabular}{|c|c|c|c|}
\hline Rightholders & $\begin{array}{c}\text { Accredited Warehouse } \\
\text { Manager }\end{array}$ & Creditor & Debtor \\
\hline $\begin{array}{c}\text { Collateral } \\
\text { documents }\end{array}$ & $\begin{array}{c}\text { Securities } \\
\text { that can be redirected }\end{array}$ & Not securities & Not securities \\
\hline $\begin{array}{c}\text { Derivative } \\
\text { Products }\end{array}$ & Yes & No & \\
\hline Registration of \\
Guarantees
\end{tabular}




\section{BIBLIOGRAPHY}

\section{Books:}

Abdul R. Saliman, Hermansyah, Ahmad Jalis, 2005, Hukum Bisnis untuk Perusahaan : Teori dan Contoh Kasus, $1^{\text {st }}$ edition (Bussines Law For Companies: Theory and Case Examples), Prenada Media Publisher, Jakarta.

H.R. Daeng Naja, 2005, Hukum Kredit dan Bank Garansi (The Bankers Hand Book), $1^{\text {st }}$ edition (Credit Law and Banking Guarantee), Citra Aditya Bakti Publisher, Bandung.

Iswi Hariyani, R Serfianto DP, 2010, Resi Gudang Sebagai Jaminan Kredit dan Alat Perdagangan (Warehouse Receipt As Credit Guarantee and Trading Tool), Sinar Grafika Publisher (Bumi Aksara Group), Jakarta.

J.A. Noertjahyo, 2005, Dari Ladang Sampai Kabinet : Menggugat Nasib Petani (From Field to Cabinet: Sues Farmers Fate), $1^{\text {st }}$ edtition, Kompas, Jakarta.

Mariam Darus Badrulzaman, 1987, Bab-Bab Tentang Creditverband, Gadai \& Fidusia (Chapters On Creditverbands, Pawn and Fidusia), $4^{\text {th }}$ edition, Alumni Publisher, Bandung,

Muhamad Djumhana, 2000, Hukum Perbankan di Indonesia (Indonesian Banking Law), $3^{\text {rd }}$ edition, Citra Aditya Bakti Publisher, Bandung.

Munir Fuady, 2000, Jaminan Fidusi (Fiduciary Guarantee), Citra Aditya Bakti Publisher, Bandung.

Oey Hoey Tiong, 1984, Fidusia Sebagai Jaminan Unsur-Unsur Perikatan (Fiduciary As A Guarantee of Engagement Elements), $1^{\text {st }}$ edition, Ghalia Indonesia Publisher, Jakarta.

R. Subekti, SH, 1982, Jaminan-Jaminan untuk Pemberian Kredit Menurut Hukum Indonesia (Guarantees For Crediting Based on The Indonesian Law), $10^{\text {th }}$ edition, Alumni Publisher, Bandung. 
R. Serfianto Dibyo Purnomo, Iswi Hariyani, Cita Yustisia Serfiyani, 2013, Pasar Komoditi : Perdagangan Berjangka dan Pasar Lelang Komoditi (Commodity Markets: Futures Trading and Commodity Auction Markets), Jogja Bangkit Publisher (Galangpress Group), Yogyakarta.

Sri Soedewi Masjchun Sofwan, 1977, Beberapa Masalah Pelaksanaan Lembaga Jaminan khususya Fiducia di dalam Praktek dan pelaksanaannya di Indoensia (Some Problems of Enforcement of Fiduciary Special Guarantee Institution in Practice and its Enforcement In Indonesia), UGM - Faculty of Law Press, Yogyakarta.

Thomas Soebroto, 1995, Tanya Jawab Hukum Jaminan : Hipotik, Fidusia, Penanggungan, dll (Legal Guarantee FAQ: Mortgage, Fiduciary, Insurance), $1^{\text {st }}$ edition, Effhar \& Dahara Prize Publisher, Semarang

\section{Journals :}

Jamin Ginting, 2008, Aspek Hukum Resi Gudang Sebagai Jaminan Hutang, Journal of Legal Reform, Vol. 11, Number 1, June 2008.

Lastuti Abubakar, 2015, Telaah Yuridis Perkembangan Lembaga dan Objek Jaminan (Gagasan Pembaruan Hukum Jaminan Nasional), Journal of Banking Law and the Central Bank, Vol. 12, Number 1, January - June 2015.

Philine Wehling, Bill Garthwaite, 2015, Designing Warehouse Receipt Legislation : Regulatory Option and Recent Trends, FAO of United Nations, Rome, 2015.

\section{Regulations:}

Law Number 4 of 1996 on Encumbrance, State Gazette of The Republic of Indonesia Number 104 of 1996

Law Number 10 of 1998 on Bank, State Gazette of The Republic of Indonesia Number 182 of 1998

Law Number 42 of 1999 on Fiduciary, State Gazette of The Republic of Indonesia Number 168 of 1999 
Law Number 37 of 2004 on Bankruptcy and Suspension of Debt Payment Obligation, State Gazette of The Republic of Indonesia Number 131 of 2004

Law Number 9 of 2006 on Warehouse Receipt System, State Gazette of The Republic of Indonesia Number 59 of 2006

Law Number 9 of 2011 on Amendment of Law Number 9 of 2006 on Warehouse Receipt System

Government Regulation of The Republic Indonesia No 36 of 2007 on The Implementation of Act No 9 of 2006 regarding Warehouse Receipt System.

Bank Indonesia Regulation No 9/6/PBI/2007 on The Second Amendment of PBI 7/2/PBI/2005 regarding Assessment of Asset Quality of Commercial Banks.

The Regulation of Minister of Trade No 26/ M-DAG/ PER/ 6/ 2007 on Goods Allowable to be Stored in Warehouse in The Administration of The Warehouse Receipt System.

The Regulation of Minister of Finance No 171/ PMK.05/ 2009 on Warehouse Receipts Subsidy Scheme.

The Regulation of Minister of Trade No 66/ M-DAG/ PER/ 12/ 2009 on The Implementation of Warehouse Receipts Subsidy Scheme. 